\title{
USO DA TEMPERATURA PARA CÁLCULO DO ÍNDICE DE SECA DE REGIÕES PRODUTORAS DE UVA ${ }^{1}$
}

\author{
MARCO ANTÔNIO FONSECA CONCEIÇÃO², JORGE TONIETTO², FLÁVIO BELLO FIALHO²
}

RESUMO- O Sistema de Classificação Climática Multicritérios Geovitícola (CCM), empregado na caracterização climática de regiões produtoras de uvas, é composto pelos índices Heliotérmico (IH), de Frio Noturno (IF) e de Seca (IS) sendo que este se baseia no balanço hídrico potencial do solo. Para se calcular os valores de IS, são necessários dados da precipitação pluvial e da evapotranspiração potencial (ETP), estimados pelo método-padrão de Penman-Monteith. Nem todas as regiões vitícolas, no entanto, apresentam as variáveis meteorológicas necessárias para o uso desse método. Daí a importância de métodos que permitem estimar a ETP com base apenas em dados da temperatura do ar, como o de Hargreaves. No presente trabalho, foram comparados os Índices de Seca calculados com base nos valores de ETP estimados, empregando-se os métodos de Penman-Monteith e Hargreaves, para diferentes regiões vitícolas do mundo. Foram utilizados dados climáticos de 83 estações meteorológicas, representativas de regiões vitícolas localizadas em 18 países. A equação de Hargreaves obteve um desempenho classificado como muito bom, podendo ser adotada no sistema CCM, quando não se dispõe de dados para o uso do método de Penman-Monteith.

Termos para indexação: viticultura, videira, zoneamento climático.

\section{USING TEMPERATURE TO CALCULATE THE DRYNESS INDEX OF GRAPE PRODUCTION REGIONS}

\begin{abstract}
The Geoviticulture Multicriteria Climatic Classification System (CCM), used to characterize the climate in grape production regions, is composed by the Heliothermal Index (HI), the Cool Night Index (CI) and the Dryness Index (DI), which is based on the potential soil water balance. The calculation of DI values requires precipitation and evapotranspiration potential (ETP) data, estimated using the standard Penman-Monteith method. However, not all grape regions have the climatic variables required to use this ETP method. Therefore, it is important to use other methods to estimate ETP based only on air temperature available data, such as the Hargreaves ETP method. The present study compared the Drought Index values calculated using the Penman-Monteith and the Hargreaves methods for different grape growing regions of the world. Climate data from 83 meteorological stations were used, representing grapevine regions located in 18 countries. The Hargreaves equation achieved a very good performance and can be used in the CCM system in places where there are insufficient data for the Penman-Monteith method.
\end{abstract}

Index terms: viticulture, grapevine, climatic zoning.

\section{INTRODUÇÃO}

O Sistema de Classificação Climática Multicritérios Geovitícola (CCM) (TONIETTO, 1999; TONIETTO ; CARBONNEAU, 2004) tem sido empregado na caracterização climática de regiões produtoras de uvas no Brasil (CONCEIÇÃO; TONIETTO, 2005; POMMER et al., 2009) e no exterior (SOTÉS et al., 2007; TONIETTO, 2008). Esse sistema é composto por três índices: o Índice Heliotérmico (IH), que é função das temperaturas mensais máxima e média do ar; o Índice de Frio Noturno (IF), que se refere à temperatura mínima do ar no último mês de maturação da uva; e o Índice de Seca (IS), que se baseia no balanço hídrico potencial do solo.
Para se calcular os valores de IS, são necessários dados da evapotranspiração de referência ou potencial (ETP), conforme nomenclatura empregada no Sistema CCM. Os valores de ETP, utilizados na determinação de IS, são estimados pelo método- padrão de Penman-Monteith-FAO. Esse método requer valores da radiação solar global, da velocidade do vento, da umidade relativa do ar e da temperatura do ar, para a estimativa de ETP (ALLEN et al., 2006).

No entanto, nem todas as regiões vitícolas apresentam séries históricas dessas variáveis climáticas, sendo comum, todavia, a existência de registros da temperatura do ar e da precipitação pluvial. Daí a importância de métodos que permitem estimar a ETP com base apenas em dados de temperatura e

${ }^{1}$ (Trabalho 092-11). Recebido em: 23-03-2011. Aceito para publicação em: 25-07-2011.

${ }^{2}$ Eng. Agrônomo, Dr. Pesquisador Embrapa Uva e Vinho, CEP95700-000, Bento Gonçalves-RS. E-mails: marcoafc@cnpuv.embrpa.br; tonietto@cnpuv.embrapa.br; bello@cnpuv.embrapa.br 
em valores estimados da radiação solar incidente no topo da atmosfera, como o de Hargreaves (ALLEN et al., 2006). Esse método tem-se mostrado adequado para estimar a ETP mensal em diversas regiões, quando só estão disponíveis registros da temperatura do ar (BACK, 2008; Lee, 2010; SABZIPARVAR; TABARI, 2010).

No presente trabalho, foram comparados os valores do Índice de Seca calculados empregando-se os métodos de Penman-Monteith e de Hargreaves, para diferentes regiões vitícolas do mundo.

\section{MATERIAL E MÉTODOS}

Foram utilizados dados climáticos de 83 estações meteorológicas, representativas de regiões vitícolas localizadas em 18 países, conforme apresentadas na Tabela 1. Observa-se que a estação de Petrolina (PE), por ser uma região de clima vitícola com variabilidade intra-anual, apresenta dois períodos de análise: de abril a setembro e de outubro a março. A base de dados utilizada, que corresponde, em geral, a séries históricas de 30 anos, está disponível na página oficial do Sistema CCM (EMBRAPA UVA e VINHO, 2010), incluindo os dados da evapotranspiração potencial estimados pelo método de Penman-Monteith (ETPPM). Os valores de ETPPM podem ser calculados empregando-se a expressão (ALLEN et al., 2006):

$$
\text { ETPPM }=\frac{0,408 \cdot s \cdot(R n-G)+\gamma \cdot 900 \cdot U_{2} \cdot\left(e_{s}-e_{a}\right) /(\text { Tmed }+273)}{\mathrm{s}+\gamma\left(1+0,34 \cdot U_{2}\right)}
$$

em que, ETPPM é a evapotranspiração potencial mensal calculada pelo método de PenmanMonteith (mm mes $\left.{ }^{-1}\right)$; s é a declividade da curva de pressão de vapor em relação à temperatura $(\mathrm{kPa}$ $\left.{ }^{\circ} \mathrm{C}^{-1}\right) ; \mathrm{Rn}$ é a radiação líquida mensal $\left(\mathrm{MJ} \mathrm{m}^{-2} \mathrm{mes}^{-1}\right)$; $\mathrm{G}$ é o fluxo mensal de calor no solo $\left(\mathrm{MJ} \mathrm{m}^{-2} \mathrm{mes}^{-1}\right)$; $\gamma$ é o coeficiente psicrométrico $\left(\mathrm{kPa}^{\circ} \mathrm{C}^{-1}\right)$; $\mathrm{U}_{2}$ é a velocidade média mensal do vento a $2 \mathrm{~m}$ de altura ( $\mathrm{m}$ $\left.\mathrm{s}^{-1}\right)$; e é a pressão de saturação de vapor $(\mathrm{kPa})$; e é a pressão parcial de vapor $(\mathrm{kPa})$; Tméd é a temperatura média mensal do ar $\left({ }^{\circ} \mathrm{C}\right)$.

Para o cálculo dos valores da ETP pelo método de Hargreaves (ETPH), foram utilizados dados mensais de temperatura máxima, média e mínima do ar e a latitude de cada local, obtidos na referida base, e a expressão obtida a partir de Allen et al. (2006):

$$
\mathrm{ETPH}=\mathrm{K} \text {. Ra } \cdot(\text { Tmáx }- \text { Tmin })^{0,5} \cdot(\text { Tmín }+17,8)
$$

em que, ETPH é a evapotranspiração po- tencial mensal calculada pelo método de Hargreaves (mm . mês $\left.{ }^{-1}\right)$; K é o coeficiente empírico da equação, igual a 0,0023 ; Ra é a radiação solar média mensal incidente no topo da atmosfera $\left(\mathrm{mm}\right.$. $\left.\mathrm{mes}^{-1}\right)$; Tmáx é o valor médio mensal da temperatura máxima do ar $\left({ }^{\circ} \mathrm{C}\right)$; Tmín é o valor médio mensal da temperatura mínima do ar $\left({ }^{\circ} \mathrm{C}\right)$; Tméd é o valor médio mensal da temperatura média do ar $\left({ }^{\circ} \mathrm{C}\right)$. Os valores de $\mathrm{Ra}$ variam com a latitude, declinação e ângulo horário solar e foram calculados segundo metodologia apresentada por Allen et al. (2006).

Os Índices de Seca (IS), obtidos empregandose os valores de ETPPM (ISPM), foram os que estão disponíveis na página oficial do Sistema CCM (EMBRAPA UVA e VINHO, 2010). Para se calcular os valores de IS a partir dos dados de ETPH (ISH), foi empregada a metodologia descrita por Tonietto e Carbonneau (2004), que se baseia no balanço hídrico potencial do solo, conforme Riou et al. (1994):

$$
\mathrm{IS}=\sum_{\mathrm{Mi}}^{\mathrm{Mf}} \mathrm{Wo}+\mathrm{P}-\mathrm{Tv}-\mathrm{Es}
$$

em que Wo é a reserva hídrica inicial do solo, que pode ser acessada pelas raízes da cultura (mm); P é a precipitação mensal ( $\mathrm{mm}$ ), cujos valores foram extraídos da página do sistema CCM; Tv é a transpiração potencial mensal do vinhedo (mm); Es é a evaporação mensal do solo (mm). Mi e Mf são, respectivamente, os meses inicial e final do ciclo da cultura. Tv foi calculada empregando-se a expressão:

$$
\text { Tv }=\text { ETPH. } \mathrm{k}
$$

em que, k é o coeficiente de absorção de radiação pelas videiras, sendo igual a 0,1 para o primeiro mês do ciclo vegetativo da cultura, 0,3 para o segundo mês e 0,5 para os demais meses. Es foi determinada pela expressão:

$$
\mathrm{Es}=(\mathrm{ETPH} / \mathrm{N}) \cdot(1-\mathrm{k}) . \mathrm{JPm}
$$

em que, N é o número de dias do mês e JPm é o número de dias por mês de evaporação efetiva do solo, que é estimado dividindo-se P por 5 e que deve ser igual ou inferior a N. Os intervalos de classe para IS estão apresentados na Tabela 2.

As comparações entre os valores de ETPPM e ETPH, e de ISPM e ISH foram obtidas por meio dos coeficientes de determinação $\left(\mathrm{R}^{2}\right) \mathrm{e}$ angulares dos modelos de regressão linear, sendo as retas forçadas a passar pela origem., , Também foi utilizado o índice c, proposto por Camargo e Sentelhas (1997) para indicar o desempenho de métodos de estimativa da evapotranspiração. $\mathrm{O}$ valor de c corresponde à multiplicação do coeficiente de correlação (r) pelo índice de concordância (d) de Willmott et al. (1985), 
que pode ser escrito da seguinte forma:

$$
\mathrm{d}=1-\left\{\sum(\mathrm{Xi}-\mathrm{Yi})^{2} / \sum(|\mathrm{Xi}-\mathrm{Ym}|+|\mathrm{Yi}-\mathrm{Ym}|)^{2}\right\}
$$

em que, d é o índice de concordância (adimensional); Xi são os valores de ETPH (mm $\mathrm{mes}^{-1}$ ) ou de ISH (mm); Yi são os valores de ETPPM $\left(\mathrm{mm} \mathrm{mes}{ }^{-1}\right)$ ou de ISPM (mm); e Ym são as médias dos valores de ETPPM $\left(\mathrm{mm} \mathrm{mes}^{-1}\right)$ ou de ISPM (mm). O desempenho foi classificado como ótimo, para valores de c maiores que 0,85 ; como muito bom para valores entre 0,76 e 0,85 ; como bom para valores entre 0,66 e 0,75 ; como regular para valores entre 0,51 e 0,65 ; como ruim para valores entre 0,41 e 0,50 ; e como péssimo para valores inferiores a 0,40 .

\section{RESULTADOS E DISCUSSÃO}

A relação entre ETPH e ETPPM apresentou coeficiente de determinação $\left(\mathrm{R}^{2}\right)$ igual a 0,90 , sendo que os valores de ETPPM foram, em média, semelhantes aos valores de ETPH, conforme o coeficiente angular $(0,97)$ observado na Figura 1. Os valores do coeficiente de correlação (r) e do índice de concordância (d) foram iguais a 0,95 e 0,98 , respectivamente, resultando em um coeficiente de desempenho (c) igual a 0,93 , que é classificado como ótimo.

Outros autores, avaliando o desempenho de valores de ETPH em relação a ETPPM, obtiveram valores de $\mathrm{R}^{2}$, em escala mensal, semelhantes aos observados no presente trabalho, como Back (2008), em Urussanga (SC); Lee (2010), em diversas localidades da Coréia do Sul, e Sabziparvar e Tabari (2010), em diferentes regiões do Irã.

Verifica-se, na Figura 1, que as maiores dispersões foram obtidas para valores de ETPPM mensais superiores a $200 \mathrm{~mm}$. Valores dessa ordem ocorrem, geralmente, em regiões mais quentes e secas, onde a advecção apresenta maior importância. Esses fatores são registrados pela equação de Penman-Monteith (eq.1), mas não pela equação de Hargreaves (eq.2). Nessas condições, entretanto, a equação de Hargreaves pode ter seus coeficientes calibrados para melhorar o seu desempenho. Gávilan et al. (2006), por exemplo, apresentaram, para a região semiárida do sul da Espanha, coeficientes de ajuste para a equação de Hargreaves em função da amplitude térmica e da velocidade média do vento. Outros autores ajustaram, por meio de regressão linear, valores do coeficiente $\mathrm{K}$ da eq. 2 para diferentes regiões (VANDERLINDEN et al., 2004; FOOLADMAND; HAGHIGHAT, 2007).

A relação dos valores do Índice de Seca, calculados pelas equações de Penman-Monteith (ISPM) e de Hargreaves (ISH), apresentou $\mathrm{R}^{2}$ igual a $0,80 \mathrm{e}$ coeficiente angular igual a 1,00 (Figura 2). O coeficiente de correlação (r) e o índice de concordância (d) foram iguais a 0,90 e 0,94 , respectivamente, resultando em um coeficiente de desempenho para ISH igual a 0,85 , que é o limite entre muito bom e ótimo. Os menores valores dos coeficientes de determinação e desempenho dos valores de ISH, quando comparados com de ETPH, devem-se ao fato de que, enquanto os valores de ETPH se referem a dados mensais, os de ISH resultam de dados acumulados durante seis meses, o que aumenta a probabilidade de se observarem maiores diferenças em relação ao ISPM.

Em 74\% das estações estudadas, as classes de ISH foram as mesmos obtidas empregando-se ISPM (Tabela 3). Nas localidades em que foram registradas diferenças, o ISH apresentou classes vizinhas às registradas pelo ISPM. Assim, por exemplo, em Córdoba (Argentina), o ISPM foi classificado como IS-1 (subúmido), enquanto o ISH foi classificado como IS+1 (seca moderada).

Nesse caso, como em outras oito regiões (Tabela 3), o uso de ISH superestimou o déficit hídrico no cálculo de IS. Na maioria das regiões, entretanto, o emprego de ISH subestimou esse déficit, fazendo com que as classes de ISH apresentassem condições mais úmidas do que as obtidas com ISPM.

Dos países com grande número de localidades avaliadas, o que registrou maiores diferenças entre ISH e ISPM foi a Espanha, em que cinco, das nove localidades, apresentaram diferenças de classes nos dois métodos. De acordo com Gavilán et al. (2008), a ETPH apresenta alta variabilidade espacial no sul da Espanha, sendo que a precisão da eq.2 é afetada pelas médias anuais da demanda evaporativa e da velocidade do vento.

De modo geral, os resultados obtidos demonstram a viabilidade do uso da equação de Hargreaves para estimativa de ETP, para a maioria das regiões vitícolas analisadas. No entanto, embora a ETPH seja uma alternativa para o cálculo do IS, quando se deseja comparar regiões, é importante a utilização da mesma metodologia de cálculo, para que não haja diferenças que são frutos da metodologia utilizada e não do clima. Também deve-se ressaltar que, para um método alternativo de cálculo da ETP, é sempre importante testar sua similaridade à ETP padrão do CCM, em função do clima e da região, já que, para alguns locais, ele pode ser um ótimo substituto e, em outras, não.

De qualquer forma, nos locais em que a ETPH for adotada, a Classificação Climática Multicritérios Geovitícola passa a depender, além da pluviometria, apenas de dados da temperatura do ar. Isso facilita, por exemplo, o zoneamento climático em grandes regiões, quando não houver disponibilidade de redes de estações meteorológicas, uma vez que os valores de temperatura podem ser estimados com base em coordenadas geográficas (ANTONINI et al., 2009). 
TABELA 1 - Relação de países e locais de origem dos dados meteorológicos utilizados.

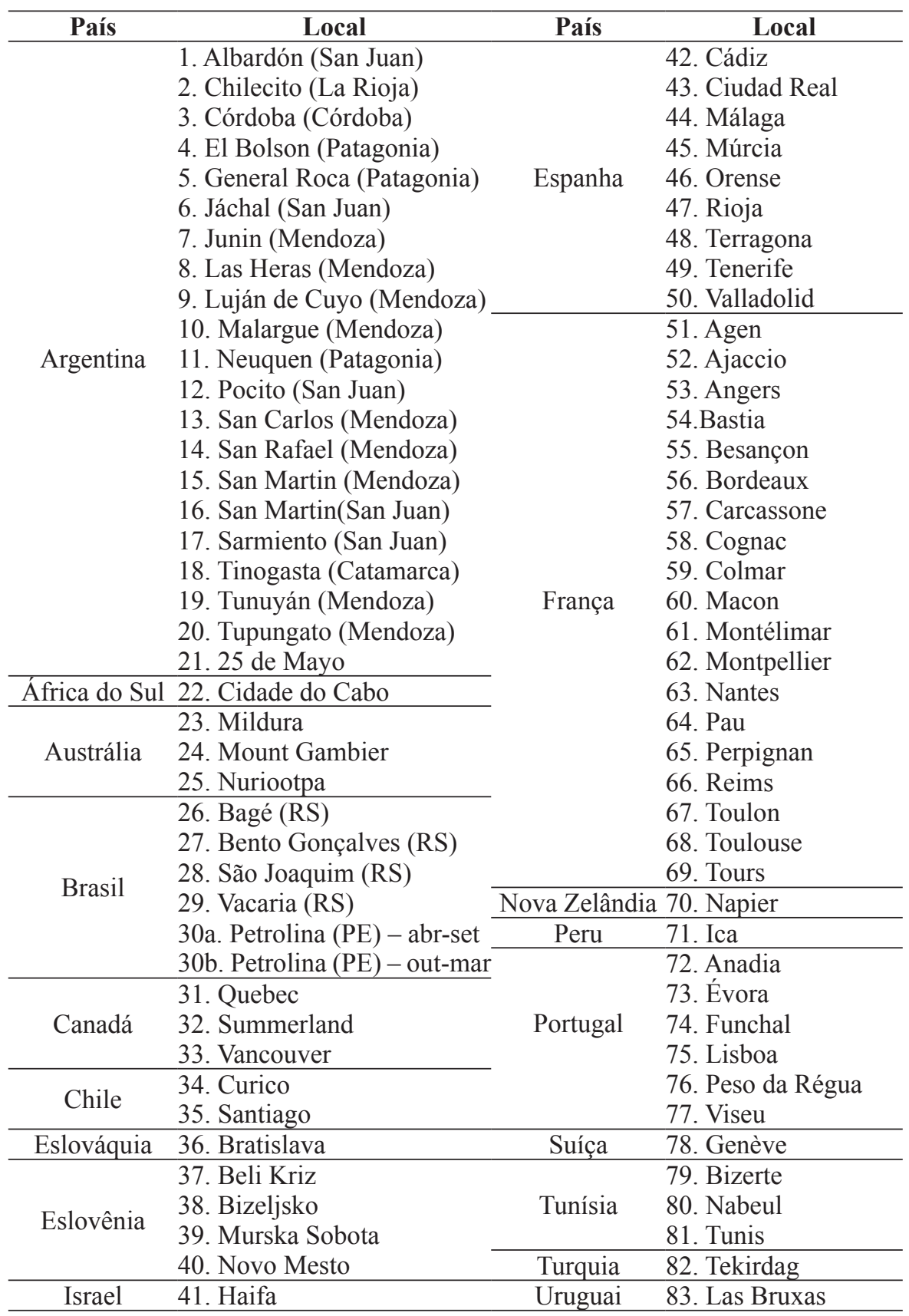

TABELA 2 - Classes e intervalos para o Índice de Seca (IS). Fonte: Tonietto e Carbonneau (2004).

\begin{tabular}{c|l|c|c}
\hline Índice climático vitícola & \multicolumn{1}{c}{ Classes do clima } & Sigla & Intervalo de classe \\
\hline \multirow{4}{*}{ Índice de Seca (IS, mm) } & Umido & IS-2 & $150<$ IS \\
\cline { 2 - 4 } & Subúmido & IS-1 & $50<$ IS $\leq 150$ \\
\cline { 2 - 4 } & De seca moderada & IS +1 & $-100<$ IS $\leq 50$ \\
\cline { 2 - 4 } & De seca forte & IS +2 & IS $\leq-100$ \\
\hline
\end{tabular}




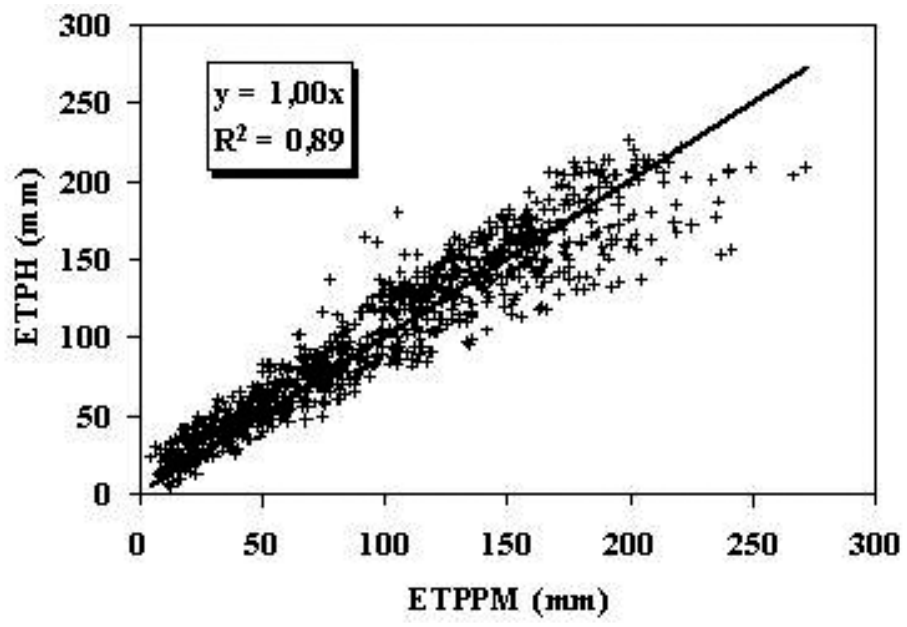

FIGURA 1 - Relação entre os valores mensais da evapotranspiração potencial calculados pelos métodos de Penman-Monteith (ETPPM) e de Hargreaves (ETPH).

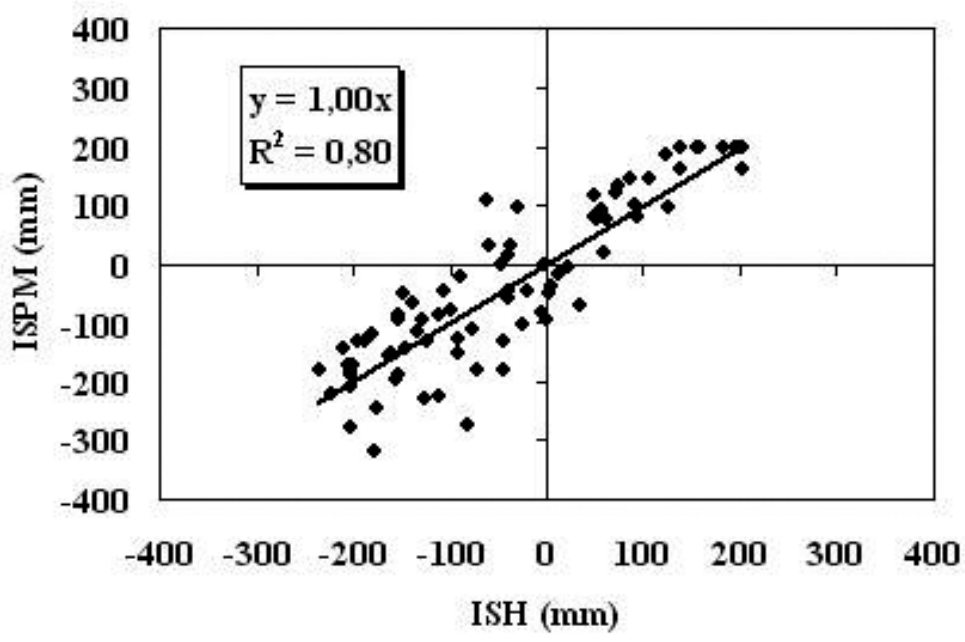

FIGURA 2 - Valores do Índice de Seca (IS) calculados empregando-se as equações de Penman-Monteith (ISPM) e de Hargreaves (ISH). 
TABELA 3 - Classes do Índice de Seca para diferentes localidades do mundo, calculados empregando-se o método de Penman-Monteith (ISPM) e de Hargreaves (ISH).

\begin{tabular}{|c|c|c|c|c|c|}
\hline $\begin{array}{c}\text { Local* } \\
\end{array}$ & ISPM & ISPH & Local* & ISPM & ISPH \\
\hline 1. Albardón (San Juan) & IS+2 & $\mathrm{IS}+2$ & 42. Cádiz & IS+2 & $\mathrm{IS}+2$ \\
\hline 2. Chilecito (La Rioja) & IS +2 & $\mathrm{IS}+2$ & 43. Ciudad Real* & IS +1 & $\mathrm{IS}+2$ \\
\hline 3. Córdoba (Córdoba)* & IS-1 & IS +1 & 44. Málaga* & IS +2 & IS +1 \\
\hline 4. El Bolson (Patagonia) & $\mathrm{IS}+1$ & IS +1 & 45. Múrcia* & IS +1 & IS +2 \\
\hline 5. G. Roca (Patagonia) & $\mathrm{IS}+2$ & $\mathrm{IS}+2$ & 46. Orense* & IS-1 & IS +1 \\
\hline 6. Jáchal (San Juan) & $\mathrm{IS}+2$ & $\mathrm{IS}+2$ & 47. Rioja & IS +1 & IS +1 \\
\hline 7. Junin (Mendoza) & $\mathrm{IS}+2$ & $\mathrm{IS}+2$ & 48. Terragona & IS +1 & IS +1 \\
\hline 8. Las Heras (Mendoza) & $\mathrm{IS}+2$ & IS +2 & 49. Tenerife* & $\mathrm{IS}+2$ & IS +1 \\
\hline 9. L. de Cuyo (Mendoza)* & IS +1 & $\mathrm{IS}+2$ & 50. Valladolid & IS +1 & IS +1 \\
\hline 10. Malargue (Mendoza) & $\mathrm{IS}+2$ & $\mathrm{IS}+2$ & 51. Agen* & IS-1 & IS +1 \\
\hline 11. Neuquen (Patagonia) & $\mathrm{IS}+2$ & IS +2 & 52. Ajaccio & $\mathrm{IS}+1$ & IS +1 \\
\hline 12. Pocito (San Juan) & $\mathrm{IS}+2$ & IS +2 & 53. Angers & IS-1 & IS-1 \\
\hline 13. San Carlos (Mendoza)* & IS +1 & IS +2 & 54.Bastia & IS +1 & IS +1 \\
\hline 14. San Rafael (Mendoza)* & IS +1 & IS +2 & 55. Besançon & IS-2 & IS-2 \\
\hline 15. S. Martin (Mendoza) & IS +2 & IS +2 & 56. Bordeaux & IS-1 & IS-1 \\
\hline 16. San Martin(San Juan) & IS +2 & IS +2 & 57. Carcassone & IS +1 & IS +1 \\
\hline 17. Sarmiento (San Juan) & $\mathrm{IS}+2$ & IS +2 & 58. Cognac & IS-1 & IS-1 \\
\hline 18.Tinogasta (Catamarca) & $\mathrm{IS}+2$ & IS +2 & 59. Colmar & IS- 1 & IS-1 \\
\hline 19. Tunuyán (Mendoza)* & IS +1 & IS +2 & 60. Macon* & IS-2 & IS-1 \\
\hline 20. Tupungato (Mendoza) & IS +1 & IS +1 & 61. Montélimar* & IS +1 & IS-1 \\
\hline 21. 25 de Mayo & IS +2 & IS +2 & 62. Montpellier & IS +1 & IS +1 \\
\hline 22. Cidade do Cabo* & IS +2 & IS +1 & 63. Nantes & IS-1 & IS-1 \\
\hline 23. Mildura & IS +2 & IS +2 & 64. $\mathrm{Pau}^{*}$ & IS-2 & IS-1 \\
\hline 24. Mount Gambier & IS +1 & IS +1 & 65. Perpignan & IS +1 & IS +1 \\
\hline 25. Nuriootpa & IS +2 & IS +2 & 66. Reims & IS-1 & IS-1 \\
\hline 26. Bagé (RS) & IS-1 & IS-1 & 67. Toulon* & IS +2 & IS +1 \\
\hline 27. Bento Gonçalves (RS) & IS-2 & IS-2 & 68. Toulouse & IS-1 & IS-1 \\
\hline 28. São Joaquim (RS) & IS-2 & IS-2 & 69. Tours & IS-1 & IS-1 \\
\hline 29. Vacaria (RS) & IS-2 & IS-2 & 70. Napier & IS-1 & IS-1 \\
\hline 30a. Petrolina (abr-set) & IS +1 & IS +1 & 71. Ica & IS +2 & $\mathrm{IS}+2$ \\
\hline 30b. Petrolina (out-mar)* & IS +2 & IS +1 & 72. Anadia & IS +1 & IS +1 \\
\hline 31. Quebec & IS-2 & IS-2 & 73. Évora* & $\mathrm{IS}+2$ & IS +1 \\
\hline 32. Summerland & IS +1 & IS +1 & 74. Funchal & IS +1 & IS +1 \\
\hline 33. Vancouver & IS-1 & IS-1 & 75. Lisboa* & $\mathrm{IS}+2$ & IS +1 \\
\hline 34. Curico & $\mathrm{IS}+2$ & $\mathrm{IS}+2$ & 76. Peso da Régua* & IS +1 & $\mathrm{IS}+2$ \\
\hline 35. Santiago & $\mathrm{IS}+2$ & $\mathrm{IS}+2$ & 77. Viseu & IS +1 & IS +1 \\
\hline 36. Bratislava & IS-1 & IS-1 & 78. Genève* & IS-2 & IS-1 \\
\hline 37. Beli Kriz & IS-2 & IS-2 & 79. Bizerte & $\mathrm{IS}+2$ & $\mathrm{IS}+2$ \\
\hline 38. Bizeljsko & IS-2 & IS-2 & 80. Nabeul* & $\mathrm{IS}+2$ & IS +1 \\
\hline 39. Murska Sobota & IS-2 & IS-2 & 81. Tunis & $\mathrm{IS}+2$ & $\mathrm{IS}+2$ \\
\hline 40. Novo Mesto & IS-2 & IS-2 & 82. Tekirdag & IS +1 & IS +1 \\
\hline 41. Haifa & IS +2 & IS +2 & 83. Las Brujas & IS-1 & IS-1 \\
\hline
\end{tabular}

*Localidades em que as classes de ISPM apresentaram valores diferentes das obtidas empregando-se ISH. 


\section{CONCLUSÃO}

O Índice de Seca (IS), calculado empregando-se a equação de Hargreaves apresenta um desempenho classificado como muito bom, em relação aos valores de IS calculados utilizando-se a equação de Penman-Monteith. Conclui-se, assim, que a equação de Hargreaves pode ser empregada para o cálculo do IS visando a determinar a classe de clima vitícola do Sistema CCM, quando não se dispõe de dados para o uso da ETP Penman-Monteith.

\section{REFERÊNCIAS}

ALLEN, R.G.; PEREIRA, L.; RAES, D.; SMITH, M. Evapotranspiración del cultivo: guías para la determinación de los requerimientos de agua de los cultivos. Roma: FAO, 2006. 298p. (Estudios FAO: Riego y Drenaje, 56).

ANTONINI, J.C. dos A.; SILVA, E.M.; OLIVEIRA, L.F.C. de; SANO, E.E. Modelo matemático para estimativa da temperatura média diária do ar no Estado de Goiás. Pesquisa Agropecuária Brasileira, Brasília, v.44, n.4, p.331-338, 2009.

BACK, A. Desempenho de métodos empíricos baseados na temperatura do ar para a estimativa da evapotranspiração de referência em Urussanga-SC. Irriga, Botucatu, v.13, n.4, p.449-466, 2008.

CAMARGO, A.P. de ; SENTELHAS, P. C. Avaliação do desempenho de diferentes métodos de estimativa da evapotranspiração potencial no Estado de São Paulo, Brasil. Revista Brasileira de Agrometeorologia, Santa Maria, v.5, n.1, p.89-97, 1997.

CONCEIÇÃO, M.A.F.; TONIETTO, J. Climatic potential for wine grape production in the tropical north region of Minas Gerais State, Brazil. Revista Brasileira de Fruticultura, Jaboticabal, v.27, n.3, p.404-407, 2005.

EMBRAPA UVA E VINHO. Consulta na base de dados mundial do Sistema CCM Geovitícola. Disponível em: $<$ http://www.cnpuv.embrapa.br/tecnologias/ccm/consulta.php $>$ Acesso em: 10 set. 2010.

FOOLADMAND, H.R.; HAGHIGHAT, M. Spatial and temporal calibration of Hargreaves equation for calculating monthly ETo based on Penman-Monteith method. Irrigation and Drainage, Hoboken, v.56, p.439-444, 2007.
GAVILÁN, P.; ESTEVEZ, J.; BERENGENA, J. Comparison of standardized reference evapotranspiration equations in Southern Spain. Journal of Irrigation and Drainage Engineering, Reston, v.134, n.1, p.1-12, 2008.

GAVILÁN, P.; LORITE, I. J.; TORNERO, S.; BERENGENA, J. Regional calibration of Hargreaves equation for estimating reference ET in a semiarid environment. Agricultural Water Management, Amsterdam, v.81, p.257-281, 2006.

LEE, K-H. Relative Comparison of the local recalibration of the temperature-based evapotranspiration equation for the Korea Peninsula. Journal of Irrigation and Drainage Engineering, Reston, v.136, n.9, p.585-594, 2010.

POMMER, C.V.; MENDES, L.S.; HESPANHOLVIANA, L.; BRESSAN-SMITH, R. Potencial climático para a produção de uvas em Campos dos Goytacazes, região norte fluminense. Revista Brasileira de Fruticultura, Jaboticabal, v.31, n.4, p.1.076-1.083, 2009.

RIOU, C. et al. Le déterminisme climatique de la maturation du raisin: application au zonage de la teneur em sucre dans la communauté européenne. Luxemburg: Office des Publications Officielles des Communautés Européennes, 1994. 322p.

SABZIPARVAR, A-A.; TABARI, H. Regional Estimation of Reference Evapotranspiration in Arid and Semiarid Regions. Journal of Irrigation and Drainage Engineering, Reston, v.136, n.10, p.724$731,2010$.

SOTÉS, V.; TONIETTO, J.; GÓMEZ-MIGUEL, V. Zonificación climática en la región vitícola iberoamericana. Enologia, Barcelona, v.4, n.2, p.1-11, 2007.

TONIETTO, J. Geographical Indicators for Grapes. Acta Horticulturae, The Hague, v.785, p.467-476, 2008.

TONIETTO, J. Les macroclimats viticoles mondiaux et l'influence du mésoclimat sur la typicité de la Syrah et du Muscat de Hambourg dans le sud de la France : méthodologie de caractérisation. 1999. 233f. (Thèse Doctorat) - École Nationale Supérieure Agronomique de Montpellier, Montpellier, 1999. 
TONIETTO, J.; CARBONNEAU, A. A multicriteria climatic classification system for grape-growing regions worldwide. Agricultural and Forest Meteorology, Amsterdam, v.124, p.81-97, 2004.

VANDERLINDEN, K.; GIRÁLDEZ, J. V.; VAN MEIRVENNE, M. Assessing Reference Evapotranspiration by the Hargreaves Method in Southern Spain. Journal of Irrigation and Drainage Engineering, Reston, v.130, n.3, p.184-191, 2004.
WILLMOTT, C.J.; ACKLESON, S.G.; DAVIS, R.E.; FEDDEMA, J.J.; KLINK, K.M.; LEGATES, D.R.; O'DONNELL, J.; ROWE, C.M. Statistics for the evaluation and comparison of models. Journal of Geophysical Research, Ottawa, v.90, n.C5, p.8.9959.005, 1985. 